Article

\title{
Development and Characterization of Polymorphic Microsatellite Markers for Sedum sarmentosum (Crassulaceae) and Their Cross-Species Transferability
}

\author{
Jing $\mathrm{Xu}$ *, Fu-Yuan Hou, Ding-Rong Wan, Sha Wang, Dong-Mei Xu and Guang-Zhong Yang \\ Received: 17 August 2015 ; Accepted: 10 October 2015 ; Published: 5 November 2015 \\ Academic Editor: Derek J. McPhee \\ College of Pharmacy, South Central University for Nationalities, 708 Minyuan Road, Wuhan 430074, China; \\ houfuyuany@sina.com (F.-Y.H.); wandr666@163.com (D.-R.W.); shaqueen@sina.com (S.W.); \\ xudongmei777@sina.com (D.-M.X.); yanggz888@126.com (G.-Z.Y.) \\ * Correspondence: xuj@mail.sceuc.edu.cn; Tel./Fax: +86-27-6784-1196
}

\begin{abstract}
Sedum sarmentosum is an important Chinese medicinal herb that exhibits anti-inflammatory, anti-angiogenic and anti-nociceptive properties. However, little is known about its genetic background. The first set of 14 microsatellite markers were isolated and characterized for S. sarmentosum using an SSR-enriched library. Fourteen polymorphic microsatellite markers were acquired with satisfactory amplifications and a polymorphic pattern in $48 \mathrm{~S}$. sarmentosum individuals. The number of alleles ranged from 3 to 15 . The observed and expected heterozygosities varied from 0.0833 to 0.8750 and 0.2168 to 0.9063 , respectively. Two loci showed significant departure from the Hardy-Weinberg equilibrium. Cross-species amplification was carried out in other Sedum species. High rates of cross-species amplification were observed. The transferability value ranged from $85.7 \%$ in S. lineare to $64.3 \%$ in S. ellacombianum. These markers will be valuable for studying the genetic variation, population structure and germplasm characterization of $S$. sarmentosum and related Sedum species.
\end{abstract}

Keywords: Sedum sarmentosum; microsatellite markers; polymorphism; genetic diversity; transferability

\section{Introduction}

The Sedum L. genus in the Crassulaceae family consists of 470 species that are distributed in the Northern Hemisphere, Africa and Latin America of Southern Hemisphere [1]. Sedum L. species are widely used in folk medicine, especially Sedum sarmentosum, which has been frequently used for the treatment of chronic hepatitis in China [2,3]. Furthermore, S. sarmentosum exhibits anti-angiogenic, anti-cancer, anti-viral and anti-nociceptive properties [4] and is attracting increasing interest from domestic and foreign pharmaceutical companies. The high demand of S. sarmentosum for medicinal uses has led to overexploitation of the wild populations, driving them close to local extinction in the wild [5]. Furthermore, the species of S. sarmentosum are difficult to identify because of the large variety and close resemblance in closely related genera. For example, it is usually morphologically confused with S. lineare [6]. Plants of the Sedum L. genus usually differ in components and activities, and therefore classification and identification of the medicinal plant species is critical to ensure quality and therapeutic efficacy. Accurate evaluation of its genetic diversity is necessary for the conservation and molecular identification of this species.

Earlier morphological and chemical composition studies have been performed for identification and classification of Sedum genus [7,8]. Allozyme markers have been used to assess the genetic relationship of two Sedum species [9]. However, little is known regarding the diversity and genetic 
structure of the Sedum genus. DNA markers, such as random amplified polymorphic DNA, have been established to study the genetic relationship of six Sedum species. However, the RAPD marker had limited ability to provide stable genetic relationship [10]. More reliable molecular markers are needed to enhance genetic analyses of Sedum species.

Microsatellite or simple sequence repeat (SSR) markers are considered to be effective in accessing genetic diversity and structure of plant population due to their abundance, high level of polymorphism, co-dominance, bi-parentally inheritance, and reproducibility of the results [11,12]. However, microsatellite markers have not been isolated from any Sedum species. In the absence of sequenced genomes, microsatellite-enrichment of genomic libraries has been shown to be effective at developing molecular markers for genetic studies [13,14]. In this study, the first set of genomic polymorphic microsatellite markers of S. sarmentosum have been developed using a microsatellite-enriched library and tested for transferability across five other Sedum species. The polymorphic microsatellite markers might have important implications for the identification, genetic diversity and population genetic structure of Sedum genus.

\section{Results and Discussion}

From the 198 colonies screened for inserts, 82 positive colonies were randomly chosen and 68 colonies were successfully sequenced, 7 colonies were duplicates. Fifty-three microsatellite motifs were discovered in 61 singleton sequences. The enrichment efficiency of microsatellites $(86.9 \%)$ was higher than for Rubus coreanus at 84.5\% [15], groundnut at 68\% [16], and Japanese apricot at $57.0 \%$ [17]. Most of the microsatellite motifs $(45,84.9 \%)$ were dinucleotides repeats, followed by trinucleotides repeats $(5,9.4 \%)$ and repeat motifs that were tetranucleotide or greater $(3,5.7 \%)$. Among the dinucleotides repeats, the GT/TG/AC/CA motifs showed the most frequency (37, 82.2\%).

38 fragments containing microsatellite motifs that showed flanking regions were used to design primers (partial results are shown in Table 1) and tested for consistency of amplification and polymorphism with $48 \mathrm{~S}$. sarmentosum. After preliminary screening, 14 polymorphic microsatellite loci yielded satisfactory amplifications with a polymorphic pattern. The number of polymorphic microsatellite loci observed with respect to amplified loci in S. sarmentosum (36.8\%) is higher than that obtained by enriched libraries constructed from other medicinal herb, such as the Dendrobium huoshanense (30.6\%) [18], Rhodiola (25.8\%) [19], and Bletilla striata (13.2\%) [20]. Several factors may account for these isolation efficiency differences, including microsatellite frequency within the genome of the studied species, structure of the microsatellites and their flanking regions [21-23].

The genetic diversity parameters of the 14 polymorphic microsatellite loci were calculated for S. sarmentosum and summarized in Table 2. The number of alleles per locus ranged from three for locus Ssa10 to 15 for locus Ssa17 with an average of 6.9 alleles/locus. The observed heterozygosity $\left(H_{\mathrm{O}}\right)$ ranged from 0.0833 to 0.8750 and the expected heterozygosity $\left(H_{\mathrm{E}}\right)$ varied from 0.2168 to 0.9063 . After sequential Bonferroni correction, two of the loci (Ssa10 and Ssa 60) showed significant departure from Hardy-Weinberg equilibrium (HWE), because of an excess of homozygotes. Null alleles, inbreeding, Wahlund effect, and small population size might lead to the excess of homozygotes [24,25]. The presence of null alleles at the microsatellite loci will be detected by software (e.g., MICRO-CHECKER [26]) and the effects of sample and habitat size will be determined in the future population genetic studies of S. sarmentosum. Among the 14 microsatellite loci, no significant linkage disequilibrium was identified between loci. 
Table 1. Characteristics of 14 polymorphic microsatellite markers isolated from S. sarmentosum.

\begin{tabular}{|c|c|c|c|c|c|}
\hline Locus & Repeat Motif & Primer Sequence $\left(5^{\prime}-3^{\prime}\right)$ & $T_{a}\left({ }^{\circ} \mathrm{C}\right)$ & Size (bp) & GenBank Accession No. \\
\hline Ssa 47 & $(\mathrm{GT})_{5}$ & $\begin{array}{l}\text { F: GGAGAAGAGAGAAGAGAGGATG } \\
\text { R: CACCGTCAAGTAATTCAGTATAAAT }\end{array}$ & 55 & 109 & KP742353 \\
\hline Ssa 30 & $(\mathrm{GT})_{7}$ & $\begin{array}{l}\text { F: TGGGTGGATTATTGATGAGG } \\
\text { R: GCTTCCTACTCAATGCAAAACC }\end{array}$ & 55 & 112 & KР742354 \\
\hline Ssa 92 & $(\mathrm{TG})_{11}$ & $\begin{array}{l}\text { F: TGGAGTGAGTTTTAGGTTTT } \\
\text { R: CACTGGAAGTGGTACGATAC }\end{array}$ & 51 & 70 & KP742355 \\
\hline Ssa 46 & $(\mathrm{TG})_{10}$ & $\begin{array}{l}\text { F: AGTGAGTTTTAGGTTTTTGTGT } \\
\text { R: AAGTGGTACGATACTATTCGC }\end{array}$ & 51 & 59 & KP742356 \\
\hline Ssa 64 & $(\mathrm{TG})_{11}$ & $\begin{array}{l}\text { F: AATGGAGTGAGTTTTAGGT } \\
\text { R: CTGGAAGTGGTACGATAC }\end{array}$ & 51 & 70 & KP742357 \\
\hline Ssa 17 & $(\mathrm{CA})_{7}$ & $\begin{array}{l}\text { F: TCAGGCTCCATAGTAACCC } \\
\text { R: AAGTCGTGTCAGGAAGGC }\end{array}$ & 57 & 173 & KP742358 \\
\hline Ssa 66B & $(\mathrm{CA})_{11}$ & $\begin{array}{l}\text { F: CTGGAAGTGGTACGATAC } \\
\text { R: GGAGTGAGTTTTAGGTTTT }\end{array}$ & 55 & 67 & KP742359 \\
\hline Ssa 56 & $(\mathrm{CA})_{12}$ & $\begin{array}{l}\text { F: TATTTCGATACTTCAATCACAC } \\
\text { R: TGTTTATTATTGACATTGAATTG }\end{array}$ & 51 & 105 & KP742360 \\
\hline Ssa 32 & $(\mathrm{CA})_{10}$ & $\begin{array}{l}\text { F: GGAAGGAGGTTTGGTAGAT } \\
\text { R: TCATCCTGTGACCCCTGT }\end{array}$ & 51 & 118 & KP742361 \\
\hline Ssa 10 & $(\mathrm{CA})_{7}-(\mathrm{CA})_{13}$ & $\begin{array}{l}\text { F: ACTGGAAGTGGTACGATACTATT } \\
\text { R: GAAATGTGTACTTACCTTATCCA }\end{array}$ & 52 & 223 & KP742362 \\
\hline Ssa 66A & $(\mathrm{GT})_{7}$ & $\begin{array}{l}\text { F: GGTTGCATTGCATAGCC } \\
\text { R: AGAATCTTCTCTCCAGAGTCA }\end{array}$ & 52 & 234 & KP742363 \\
\hline Ssa 83 & $(G T)_{8}$ & $\begin{array}{l}\text { F: AGGAAGGCGAATGAGTGT } \\
\text { R: AAGAAGGTGAAATGTATAGCA }\end{array}$ & 55 & 153 & KP742364 \\
\hline Ssa 60 & $($ TGTTGTG) 6 & $\begin{array}{l}\text { F: GCTTCTTGCTGAAAGTGACA } \\
\text { R: ACGACAGGTTTCCCGACT }\end{array}$ & 55 & 243 & KP742366 \\
\hline Ssa 90 & $(\mathrm{TG})_{5}$ & $\begin{array}{l}\text { F: AACAACAGGTTATACCACTTCG } \\
\text { R: CCACACAAACACACGCAC }\end{array}$ & 54 & 128 & KP742365 \\
\hline
\end{tabular}

Annealing temperature $\left(T_{a}\right)$.

Table 2. Genetic diversity of microsatellite marker for S. sarmentosum and S. lineare.

\begin{tabular}{ccccccccc}
\hline \multirow{2}{*}{ Locus } & \multicolumn{3}{c}{ Sedum sarmentosum $(\boldsymbol{n}=\mathbf{4 8 )}$} & \multicolumn{4}{c}{ Sedum lineare $(\boldsymbol{n}=\mathbf{1 2})$} \\
\cline { 2 - 9 } & $\boldsymbol{A}$ & $\boldsymbol{H}_{\mathbf{O}}$ & $\boldsymbol{H}_{\mathrm{E}}$ & $\boldsymbol{P}_{H W E}$ & $\boldsymbol{A}$ & $\boldsymbol{H}_{\mathbf{O}}$ & $\boldsymbol{H}_{\mathrm{E}}$ & $\boldsymbol{P}_{H W E}$ \\
\hline Ssa 47 & 6 & 0.5892 & 0.5833 & 0.6073 & - & & & \\
Ssa 30 & 5 & 0.4583 & 0.5052 & 0.0612 & 1 & & & \\
Ssa 92 & 8 & 0.6458 & 0.6516 & 0.8734 & 4 & 0.2033 & 0.2964 & 0.0312 \\
Ssa 46 & 6 & 0.5833 & 0.6038 & 0.9824 & 1 & & & \\
Ssa 64 & 7 & 0.6471 & 0.5882 & 0.6667 & 5 & 0.45 & 0.5018 & 0.3506 \\
Ssa 17 & 15 & 0.8750 & 0.9011 & 0.1823 & 7 & 0.5 & 0.6012 & 0.2021 \\
Ssa 66B & 5 & 0.4512 & 0.3958 & 0.4612 & 6 & 0.4583 & 0.5821 & $\mathbf{0 . 0 0 0 0}$ \\
Ssa 56 & 10 & 0.8333 & 0.9063 & 0.0672 & 6 & 0.4167 & 0.5623 & 0.0313 \\
Ssa 32 & 4 & 0.4167 & 0.4920 & 0.7343 & 1 & & & \\
Ssa 10 & 3 & 0.0833 & 0.2168 & $\mathbf{0 . 0 0 0 0}$ & 1 & & & \\
Ssa 66A & 8 & 0.5833 & 0.6328 & 0.1273 & - & & & \\
Ssa 83 & 7 & 0.5417 & 0.6027 & 0.4263 & 1 & & & \\
Ssa 60 & 4 & 0.2500 & 0.4328 & $\mathbf{0 . 0 0 0 3}$ & 1 & & & \\
Ssa 90 & 9 & 0.7033 & 0.7108 & 0.6230 & 3 & 0.3333 & 0.3367 & 0.0421 \\
\hline
\end{tabular}

Number of alleles $(A)$, observed heterozygosity $\left(H_{\mathrm{O}}\right)$, expected heterozygosity $\left(H_{\mathrm{E}}\right)$, and the test for deviation from Hardy-Weinberg Equilibrium $\left(P_{\mathrm{HWE}}\right)$. Values in bold represent significant deviation from Hardy-Weinberg equilibrium.

Cross-species amplification tests were performed in the S. lineare, which is morphologically close to $S$. sarmentosum. Twelve of the 14 microsatellite markers were amplified successfully and only six showed polymorphism in $12 \mathrm{~S}$. lineare individuals (Table 2), which may result from the small size of the populations. The number of alleles per locus ranged from 3 to 7 , the $H_{\mathrm{O}}$ ranged from 0.2033 to 0.5000 and $H_{\mathrm{E}}$ varied from 0.2964 to 0.6012 (Table 2). Among the six polymorphic microsatellite loci, only one locus (Ssa 66B) deviated significantly from HWE. This result showed that the microsatellite primers could be used in S. lineare and selective use of the primers could effectively discriminate S. sarmentosum from S. lineare. 
We also applied the 14 microsatellite markers to test their transferability to other four Sedum species (S. emarginatum, S. bulbiferum, S. aizoo and S. ellacombianum, Supplementary Table). The tested SSR primer pairs displayed a high amplification frequency across the species. A total of eight (57.1\%) markers successfully amplified in all the four other Sedum species. The transferability value was highest in S. emarginatum (78.6\%), followed by S. bulbiferum (71.4\%) and S. aizoo (71.4\%) (Table 3). S. ellacombianum showed the lowest transferability, only $64.3 \%$. Wu et al. used PAPD to study the genetic relationship of six Sedum species. The phylogenetic analysis revealed that S. sarmentosum and $S$. lineare had the nearest the distance and grouped in one clade, while S. ellacombianum was in another clade [10]. The transferability of the SSR markers obtained by enriched libraries was a little lower than that by sequencing, which was expected due to the conservative nature of transcribed regions [27-29].

Table 3. Transferability of 14 microsatellite markers for the Sedum genus.

\begin{tabular}{lcccccc}
\hline & \multicolumn{7}{c}{ Sedum Species } \\
\cline { 2 - 7 } & $\begin{array}{c}\text { S. sarmentosum } \\
(\boldsymbol{n}=\mathbf{1 2})\end{array}$ & $\begin{array}{c}\text { S. lineare } \\
(\boldsymbol{n}=\mathbf{1 2})\end{array}$ & $\begin{array}{c}\text { S. emarginatum } \\
(\boldsymbol{n}=3)\end{array}$ & $\begin{array}{c}\text { S. bulbiferum } \\
(\boldsymbol{n}=3)\end{array}$ & $\begin{array}{c}\text { S. aizoo } \\
(\boldsymbol{n}=3)\end{array}$ & $\begin{array}{c}\text { S. ellacombianum } \\
(\boldsymbol{n}=\mathbf{3})\end{array}$ \\
\hline Transferability $(\%)$ & 100 & 85.7 & 78.6 & 71.4 & 71.4 & 64.3 \\
\hline
\end{tabular}

\section{Experimental Section}

\subsection{Plant Materials and Genomic DNA Extraction}

Forty-eight individuals of $S$. sarmentosum were collected from a single population located in Hongshan District, Wuhan, China $\left(30^{\circ} 29^{\prime} 22^{\prime \prime} \mathrm{N}, 114^{\circ} 23^{\prime} 15^{\prime \prime} \mathrm{E}\right)$. Leaves were randomly sampled and immediately put into the plastic sealed bags with silica gel for fast drying and then stored at room temperature until use. Genomic DNA was extracted from silica-gel-dried leaves using a $2 \%$ CTAB protocol with minor modification [30]. The DNA concentration was determined using an ultraviolet-visible spectrophotometer (ND-1000; NanoDrop, Wilmington, DE, USA). The final concentration of each DNA sample was adjusted to $20 \mathrm{ng} / \mu \mathrm{L}$ in TE buffer and kept at $-30{ }^{\circ} \mathrm{C}$ until use.

\subsection{Construction of an SSR-Enriched Library and Primer Design}

DNA was digested using the restriction enzyme MseI (Promega, Madison, WI, USA) and the digested DNA was ligated to a double-strand linker by $\mathrm{T}_{4}$ DNA ligase (TaKaRa, Dalian, China). Then linker-ligated DNA was amplified by 17 cycles of pre-hybridization polymerase chain reaction (PCR) using one strand of the linker as primer. The enriched DNA fragments were denatured and hybridized to biotinylated probes $(\mathrm{AC})_{15}$ followed by incubation with Streptavidin MagneSphere Paramagnetic Particles (Promega, Madison, WI, USA). The captured DNA fragments were used as templates for 33 cycles of PCR amplification using an adaptor as primers. Following amplification, DNA fragments were size-selected (200 to $1000 \mathrm{bp}$ ) and purified on agarose gels. The fragments were ligated to pMD18-T vectors and transformed into Escherichia coli DH5a competent cells to construct an enriched microsatellite library. Recombinant colonies, identified as white colonies on an LB plate containing ampicillin were screened for inserts using M13 primers and we randomly chose 82 positive colonies to sequence. Tandem Repeats Finder [31] was used to identify the SSR motif and Primer Premier 5.0 software [32] was used to design primers flanking the tandem repeat region in the sequence.

\subsection{Amplification of SSR, Polymorphism Detection and Data Analysis}

The M13-tailed primer method, in which the M13 sequence is attached to the $5^{\prime}$-end of the forward primer, was used to determine the sizes of the amplified products [33]. Microsatellite amplification conditions consisted of $20 \mu \mathrm{L}$ PCR reaction volumes, which containing $50 \mathrm{ng}$ of genomic DNA, $0.2 \mathrm{mM}$ of each dNTP, 1X Taq polymerase buffer (containing $1.5 \mathrm{mM} \mathrm{MgCl}_{2}$ ), 
2 pmol of M13-tailed-forward primer, 4 pmol of the fluorescently labeled M13 universal primer (5'-TGT AAA ACG GCC AGT-3'), 6 pmol of a normal reverse primer, and $1 \mathrm{U}$ of DNA Polymerase (Takara, Dalian, China). The temperature profile was as follows: $5 \mathrm{~min}$ initial denaturation at $95{ }^{\circ} \mathrm{C}$, followed by 34 cycles of denaturation at $94{ }^{\circ} \mathrm{C}$ for $30 \mathrm{~s}$, annealing at $51-57{ }^{\circ} \mathrm{C}$ for $30 \mathrm{~s}$, extension at $72{ }^{\circ} \mathrm{C}$ for $1 \mathrm{~min}$ and the final extension step of $7 \mathrm{~min}$ at $72{ }^{\circ} \mathrm{C}$. The PCR products were electrophoresed on an ABI 3730 genetic analyzer and allele sizes were determined using GeneMapper v4.0 software (Applied Biosystems). The number of alleles per locus (A) and observed $\left(H_{\mathrm{O}}\right)$ and expected $\left(H_{\mathrm{E}}\right)$ levels of heterozygosity were calculated using the Arlequin program Version 3.5 [34]. Hardy-Weinberg Equilibrium (HWE) and linkage disequilibrium (LD) was tested using the GENEPOP program Version 4.0 [35].

\subsection{Detection of the Transferability of SSR Primers and Date Analysis}

Cross-species amplification tests were performed in randomly selected S. lineare $(n=12)$, S. emarginatum $(n=3)$, S. bulbiferum $(n=3)$, S. aizoo $(n=3)$, and S. ellacombianum $(n=3)$. The PCR conditions of each loci and the calculation of the genetic diversity parameters were the same as described earlier.

\section{Conclusions}

This is the first set of microsatellite markers developed for S. sarmentosum, an important Chinese medicinal herb. A total of 14 polymorphic SSR markers were ultimately screened and proved in S. sarmentosum. The SSR primer pairs displayed a high amplification frequency across Sedum species. These markers will be valuable for studying the genetic variation, population structure and germplasm characterization of S. sarmentosum and related Sedum species and aid in the development of conservation practices for $S$. sarmentosum.

Supplementary Materials: Supplementary materials can be accessed at: http://www.mdpi.com/1420-3049/ 20/11/19669/s1.

Acknowledgments: The study was supported by the National Natural Science Foundation of China (Grant: 31302172), Universities of Hubei Province Outstanding Youth Scientific Innovation Team Plan (Grant: T201220), and Hubei Engineering Technology Center of National Medicine Modernization (Grant: 2015ZY004).

Author Contributions: Jing $\mathrm{Xu}$, Ding-Rong Wan and Guang-Zhong Yang conceived and designed the experiments; Fu-Yuan Hou, Sha Wang and Dong-Mei Xu performed the experiments; Guang-Zhong Yang analyzed the data; Jing Xu wrote the manuscript. All authors read and approved the manuscript.

Conflicts of Interest: The authors declare no conflict of interest.

\section{References}

1. Wang, D.R. A Survey of "Chuipencao" and the other ethnomedicines from the same genus (Sedum L.). Lishizhen Med. Mat. Med. Res. 2007, 18, 1853-1855.

2. Wu, X.N. Update therapy of chronic hepatitis B in China: Recent progress. China Natl. J. New Gas. 1996, 2, 65-68.

3. Kang, T.H.; Pae, H.O.; Yoo, J.C.; Kim, N.Y.; Kim, Y.C.; Ko, G.I.; Chung, H.T. Antiproliferative effects of alkaloids from Sedum sarmentosum on murine and human hepatoma cell lines. J. Ethnopharmacol. 2000, 70, 177-182. [CrossRef]

4. Jung, H.J.; Kang, H.J.; Song, Y.S.; Park, E.H.; Kim, Y.M.; Lim, C.J. Anti-inflammatory, anti-angiogenic and anti-nociceptive activities of Sedum sarmentosum extract. J. Ethnopharmacol. 2008, 116, 138-143. [CrossRef] [PubMed]

5. Liu, M.Z.; Luo, K.; Yao, H.; Liu, P. Authentication of sedum sarmentosum and its adulterants by application of ITS2 sequences. Mod. Chin. Med. 2011, 13, 29-31.

6. Xie, D.M.; Huang, L.Q.; Qin, M.J.; Wang, D.Q.; Jiang, C.; Yuan, Y. AS-PCR amplification in identification of Sedum sarmentosum with its relative species. J. Chin. Med. Mat. 2014, 37, 1768-1772. 
7. Wu, F.X. Authentication of Sedum sarmentosum and its adulterants. Yunnan J. Tradit. Chin. Med. Mater. Med. 2008, 29. [CrossRef]

8. Lu, L.Q.; Mei, Q.; Wan, D.R.; Yang, X.Z.; Qiao, S.; Zhao, Y.D. HPLC characteristic fingerprints of sedi linearis herba and sedi herba. J. Chin. Med. Mat. 2014, 37, 583-587.

9. Chung, M.Y.; López-Pujol, J.; Chung, M.G. Comparative genetic structure between Sedum ussuriense and Sedum kamtschaticum (Crassulaceae), two stonecrops co-occurring on rocky cliffs. Am. J. Bot. 2014, 101, 946-956. [CrossRef] [PubMed]

10. Wu, H.J.; Xu, R.; Wan, D.R.; Chen, Y. Genetic diversity analysis on the medicinal plants of Sedum L. by RAPD. J. Huazhong Agric. Univ. 2008, 27, 782-786.

11. Varshney, R.K.; Graner, A.; Sorrells, M.E. Genic microsatellite markers: Features and applications. Trends Biotechnol. 2005, 23, 48-55. [CrossRef] [PubMed]

12. Sharma, P.C.; Grover, A.; Kahl, G. Mining microsatellites in eukaryotic genomes. Trends Biotechnol. 2007, 25, 490-498. [CrossRef] [PubMed]

13. Glenn, T.C.; Schable, N.A. Isolating microsatellite DNA loci. Method Enzymol. 2005, 395, 202-222.

14. Techen, N.; Arias, R.S.; Pan, Z.; Khan, I.A.; Scheffler, B.E. Optimized construction of microsatellite-enriched libraries. Mol. Ecol. Res. 2010, 10, 508-515. [CrossRef] [PubMed]

15. Lee, G.A.; Song, J.Y.; Choi, H.R.; Chung, J.W.; Jeon, Y.A.; Lee, J.R.; Ma, K.H.; Lee, M.C. Novel microsatellite markers acquired from Rubus coreanus Miq. and cross-amplification in other Rubus species. Molecules 2015, 20, 6432-6442. [CrossRef] [PubMed]

16. Cuc, L.M.; Mace, E.S.; Crouch, J.H.; Quang, V.D.; Long, T.D.; Varshney, R.K. Isolation and characterization of novel microsatellite markers and their application for diversity assessment in cultivated groundnut (Arachis hypogaea). BMC Plant Biol. 2008, 8. [CrossRef] [PubMed]

17. Kwon, S.W.; Chung, J.W.; Park, J.W.; Lee, G.A.; Ma, K.H.; Lee, M.C.; Park, Y.J. Microsatellite variations and population structure in an on-farm collection of Japanese apricot (Prunus mume Sieb. et Zucc.). Biochem. Syst. Ecol. 2012, 42, 99-112. [CrossRef]

18. Wang, H.; Chen, N.F.; Zheng, J.Y.; Wang, W.C.; Pei, Y.Y.; Zhu, G.P. Isolation and characterization of eleven polymorphic microsatellite loci for the valuable medicinal plant Dendrobium huoshanense and cross-species amplification. Int. J. Mol. Sci. 2012, 13, 16779-16784. [CrossRef] [PubMed]

19. You, J.L.; Liu, W.S.; Zhao, Y.; Zhu, Y.Q.; Zhang, W.J.; Wang, Y.G.; Lu, F.; Song, Z.P. Microsatellite markers in Rhodiola (Crassulaceae), a medicinal herb genus widely used in traditional Chinese medicine. Appl. Plant Sci. 2013, 1. [CrossRef]

20. Zhang, Y.S.; Hou, B.W.; Zhang, W.M.; Ding, X.Y. Isolation and characterization of novel microsatellite markers for Bletilla striata and inter-specific amplification in 2 congeneric species. Conserv. Genet. Resour. 2015, 7, 483-485. [CrossRef]

21. Nève, G.; Meglécz, E. Microsatellite frequencies in different taxa. Trends Ecol. Evol. 2000, 15, 376-377. [CrossRef]

22. Meglécz, E.; Petenian, F.; Danchin, E.; Coeur d'Acier, A.; Rasplus, J.Y.; Faure, E. High similarity between flanking regions of different microsatellites detected within each of two species of Lepidoptera: Parnassius apollo and Euphydryas aurinia. Mol. Ecol. 2004, 13, 1693-1700. [CrossRef] [PubMed]

23. Nantón, A.; Arias-Pérez, A.; Méndez, J.; Freire, R. Characterization of nineteen microsatellite markers and development of multiplex PCRs for the wedge clam Donax trunculus (Mollusca: Bivalvia). Mol. Biol. Rep. 2014, 41, 5351-5357. [CrossRef] [PubMed]

24. Geng, Q.F.; Liu, J.; Sun, L.; Liu, H.; Ou-Yang, Y.; Cai, Y.; Tang, X.S.; Zhang, H.W.; Wang, Z.S.; An, S.Q. Development and characterization of polymorphic microsatellite markers (SSRs) for an endemic plant, Pseudolarix amabilis (Nelson) Rehd. (Pinaceae). Molecules 2015, 20, 2685-2692. [CrossRef] [PubMed]

25. Zouros, E.; Foltz, D.W. Possible explanations of heterozygote deficiency in Bivalve mollusks. Malacologia 1984, 25, 583-591.

26. Chapuis, M.P.; Estoup, A. Microsatellite null alleles and estimation of population differentiation. Mol. Biol. Evol. 2007, 24, 621-631. [CrossRef] [PubMed]

27. Chen, X.B.; Xie, Y.H.; Sun, X.M. Development and characterization of polymorphic Genic-SSR markers in Larix kaempferi. Molecules 2015, 20, 6060-6067. [CrossRef] [PubMed]

28. Wu, J.; Cai, C.F.; Cheng, F.Y.; Cui, H.L.; Zhou, H. Characterisations and development of EST-SSR markers in tree peony using transcriptome sequences. Mol. Breed. 2014, 34, 1853-1866. [CrossRef] 
29. Wang, H.X.; Walla, J.A.; Zhong, S.B.; Huang, D.Q.; Dai, W.H. Development and cross-species/genera transferability of microsatellite markers discovered using 454 genome sequencing in chokecherry (Prunus virginiana L.). Plant Cell Rep. 2012, 31, 2047-2055. [CrossRef] [PubMed]

30. Lian, C.L.; Hogetsu, T.; Matsushita, N.; Guerin-Laguette, A.; Suzuki, K.; Yamada, A. Development of microsatellite markers from an ectomycorrhizal fungus, Tricholoma matsutake, by an ISSR-suppression-PCR method. Mycorrhiza 2003, 13, 27-31. [CrossRef] [PubMed]

31. Benson, G. Tandem repeats finder: A program to analyze DNA sequences. Nucleic Acids Res. 1999, 27, 573-580. [CrossRef] [PubMed]

32. Abd-Elsalam, K.A. Bioinformatic tools and guideline for PCR primer design. Afr. J. Biotechnol. 2003, 2, 91-95. [CrossRef]

33. Schuelke, M. An economic method for the fluorescent labeling of PCR fragments. Nat. Biotechnol. 2000, 18, 233-234. [CrossRef] [PubMed]

34. Excoffier, L.; Lischer, H.E.L. Arlequin suite ver 3.5: A new series of programs to perform population genetics analyses under Linux and Windows. Mol. Ecol. Resour. 2010, 10, 564-567. [CrossRef] [PubMed]

35. Raymond, M.; Rousset, F. GENEPOP (version 1.2): Population genetics software for exact tests and ecumenicism. J. Hered. 1995, 86, 248-249.

Sample Availability: Samples are available from the authors.

(C) 2015 by the authors; licensee MDPI, Basel, Switzerland. This article is an open access article distributed under the terms and conditions of the Creative Commons by Attribution (CC-BY) license (http://creativecommons.org/licenses/by/4.0/). 